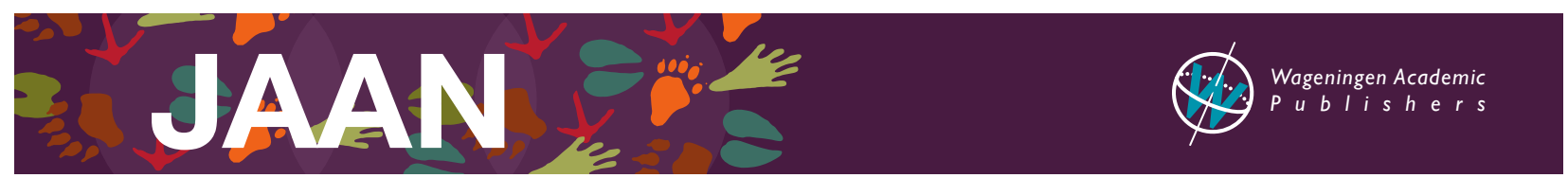

\title{
Effects of dietary inclusion of GuarPro F-71 on the growth performance and nutrient metabolism in young growing pigs
}

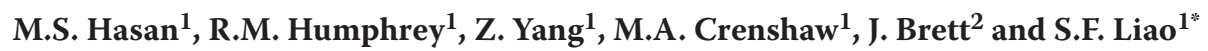 \\ ${ }^{1}$ Department of Animal and Dairy Sciences, Mississippi State University, P.O. Box 9815, Mississippi State, MS 39762, USA; \\ ${ }^{2}$ Department of Veterinary Pathobiology and Population Medicine, Mississippi State University, P.O. Box 6100, Mississippi \\ State, MS 39762,USA; s.liao@msstate.edu
}

Received: 14 September 2020 / Accepted: 12 October 2020

(c) 2020 M.S. Hasan et al.

\section{RESEARCH ARTICLE}

\begin{abstract}
Using alternative feedstuffs can be a feasible measure to reduce swine production cost. GuarPro F-71 (GP71), a newly developed guar meal product, is considered as a potential protein source for pigs. This preliminary study was conducted to evaluate the effects of GP71 inclusion in feed on growth performance and nutrient metabolism of growing pigs. Sixty crossbred barrows $(31.9 \pm 1.84 \mathrm{~kg}$ body weight $(\mathrm{BW}))$ were allotted to one of five dietary treatments in a completely randomised experiment design, with four pens/treatment and three pigs/pen. Diet 1 was a maizeand soybean-based basal control diet formulated to meet NRC recommendations. GP71 was used to replace 25, 50,75 , and $100 \%$ soybean meal in diet 1 (on an equivalent crude protein (CP) basis) to generate diets $2,3,4$, and 5 , respectively. Crystalline amino acids were used to balance the essential amino acid concentrations across the five diets. Inclusion of GP71 quadratically reduced average daily feed intake (ADFI) ( $P=0.01)$ with no observed clinical signs of unhealthiness of pigs. The blood plasma concentrations of six metabolites, including urea nitrogen, total protein, albumin, glucose, total cholesterol and total triglycerides, were not affected $(P>0.30)$, indicating that the pigs' metabolic utilisation of nutrients was not compromised. The cubic effect $(P<0.05)$ of dietary GP71 inclusion on G:F ratio suggested that the level of soybean meal replacement (up to $75 \%$ soybean meal) did not negatively affect feed efficiency in pigs. In short, the feed intake reduction due to the dietary GP71 inclusion was, if not solely, responsible for the average daily gain (ADG) and final BW reduction. This study suggested that using GP71 to replace soybean meal up to $75 \%$ (on an equivalent CP basis) can negatively affect ADFI and ADG, but not feed efficiency, in growing pigs. The reasons for the ADFI and ADG reduction need to be understood in future research.
\end{abstract}

Keywords: guar meal, pig, growth performance, nutrient metabolite

\section{Introduction}

Feed cost represents roughly 60 to $70 \%$ of the total commercial pork production expenses, and high feed cost has become a major concern for the swine industry (Patience et al., 2015; Velayudhan et al., 2015). Hence, the swine producers and nutritionists have been searching for alternative feedstuffs that can be used in swine diets to reduce feed cost. Conventionally, cereal grains (such as maize, sorghum, and barley) and oilseed meals (such as soybean meal and rapeseed meal) are commonly used to formulate the 'best' diets at least cost for raising pigs in the US (McGlone and Pond, 2003). However, unconventional feed ingredients (e.g. distiller dried grain with solubles), if production and nutrient availability are sufficient, can be included in swine diets to reduce feed costs without affecting growth performance (Kim et al., 2017; Schmit et al., 2009).

Guar meal (a.k.a., guar korma) is a by-product from the production of guar gum (which is used to produce guaran or galactomannans) from processing of guar (Cyamopsis 
tetragonoba L.) seeds (Mudgil et al., 2014). The economic value of guar meal can be regarded as a 'salvage' market (Conner, 2002). Although less palatable and potentially toxic, guar meal has a great potential as an alternative protein source for livestock and poultry, because of its high levels (nearly 59 to $60 \%$ crude protein (CP)) and less expensive (Couch et al., 1967; Humphrey et al., 2018; Kamran et al., 2002; Lee et al., 2005). Guar meal meets the criteria defined by Kim et al. (2017) to be considered as an alternative feedstuff; however, it has not yet been adopted in the NRC (2012) database for swine. Therefore, it has been hypothesised that the commercial source GuarPro F-71 (GP71) can totally or partially replace soybean meal as a dietary protein source for swine, without compromising growth performance.

Dietary inclusion of guar meal has already been studied in poultry (Gutierrez et al., 2007; Lee et al., 2003, 2005; Vohra and Kratzer, 1964), dairy cows (Rahman and Leighton, 1968), sheep (Huston and Shelton, 1971), and pigs (Heo et al., 2009). According to Conner (2002), inclusion of 2.5\% untreated guar meal in a maize-soybean meal-based diet did not compromise growth, feed intake, feed efficiency or meat yield of broilers. In contrast, high inclusion level can depress feed efficiency and growth in animals, because of the presence of antinutritional factors and poor palatability (Gutierrez et al., 2007). Prior to diet formulation, animal nutritionists must understand the acceptable usage rate of guar meal in swine diets. Therefore, the objective of this preliminary study was to test this hypothesis by: (1) determining the maximal dietary inclusion rate of guar meal using a dose-response method; and (2) studying the effects dietary guar meal inclusion on the plasma levels of some metabolites from major nutrients in growing pigs.

\section{Materials and methods}

\section{Animal trial procedure}

All experimental procedures involving caring, handling, and treatment of the pigs were approved by the Mississippi State University Institutional Animal Care and Use Committee. A total of 60 crossbred (Yorkshire $\times$ Landrace) growing barrows, purchased from a local commercial farm, were transferred into an environment-controlled swine barn at the Leveck Animal Research Center at Mississippi State University (Starkville, MS, USA). On arrival, pigs were sorted into 20 pens (three pigs/pen) based on body weight (BW) similarity in each individual pen (to avoid aggression). Pigs were allowed to adapt to the barn environment for one week whilst being fed a commercial grower diet (ADM Animal Nutrition, Quincy, IL, USA). After adaptation, when pig $B W$ reached $31.9 \pm 1.84 \mathrm{~kg}$ (average, $\mathrm{n}=60$ ), the pens were assigned to one of five dietary treatments, in a completely randomised experimental design $(n=4)$, where each pen served as an experimental unit.
A total of five experimental diets (Table 1) were formulated to meet or exceed the nutrient requirements, as recommended by NRC (2012) for 30 to $50 \mathrm{~kg}$ growing pigs. Diet 1 was the basal control diet formulated with maize and soybean meal. Diets 2, 3, 4, and 5 were formulated with inclusion of GP71 (Shree Ram India Gums Pvt Ltd, Rajasthan, India) to replace $25 \%, 50 \%, 75 \%$, and $100 \%$ soybean meal (on an equivalent CP basis), respectively. The nutrient profiles, including amino acids and minerals of GP71 have been previously reported (Humphrey et al., 2018; Liao et al., 2018). The vitamin profile and some antinutritional factors contained in GP71 are provided in supplemental Table S1.

Crystalline amino acids were supplied to balance the dietary levels of essential amino acids, which included lysine, methionine, threonine, isoleucine, valine, cysteine, phenylalanine, and tryptophan across all the five diets, and the same was done for digestible and net energy, where poultry fat was added. Since the CP content of guar meal is greater than that of soybean meal (i.e. $58.6 \mathrm{vs} 47.3 \%$ ), the amounts of guar meal used in each diet were less than that of soybean meal replaced (in terms of weight) to reach the corresponding dietary $\mathrm{CP}$ level. The analysed major nutrient parameters of the five experimental diets are shown in Table 1 , and the calculated nutrient composition is shown in supplemental Table S2.

Pigs had ad libitum access to the experimental diets and fresh water for four weeks. All feeders and drinkers were checked two to three times daily (7:00 am to 9:00 pm). Pigs' BW and feed consumption were measured at the beginning and the end of the feeding trial. The growth performance parameters including average daily gain (ADG), average daily feed intake (ADFI), and gain:feed (G:F) ratio was calculated accordingly.

\section{Sample collections and laboratory analyses}

Three samples per diet were collected from the five diets and were submitted to the Essig Animal Nutrition Laboratory, Mississippi State University (Starkville, MS, USA) for gross energy determination and proximate analyses of major nutrients, that included dry matter, CP, crude fibre, fat (as ether extract) and ash. The results are presented in Table 1.

At the end of the four-week feeding trial, blood samples were collected by jugular vein venipuncture (approximately $10 \mathrm{ml} / \mathrm{pig}$ ) in the early morning (between 6:00 and 8:00 am). Pigs were fasted overnight before the blood collection to avoid any elevated post prandial concentrations of nutrients. Immediately after collection, blood samples were kept on ice until further processing, which was done within $30 \mathrm{~min}$ after collection. Plasma was separated from each blood sample by centrifugation at $4{ }^{\circ} \mathrm{C}$ and $800 \times g$ for $10 \mathrm{~min}$. Plasma samples were aliquoted into $500 \mu \mathrm{l}$ Eppendorf tubes 
Table 1. Compositions of dietary ingredients and major nutrients of the experimental diets fed to the growing pigs used in the study (as-fed basis). ${ }^{1}$

\begin{tabular}{|c|c|c|c|c|c|}
\hline \multirow[t]{2}{*}{ Item } & \multicolumn{5}{|c|}{ Experimental diets } \\
\hline & Diet 1 & Diet 2 & Diet 3 & Diet 4 & Diet 5 \\
\hline \multicolumn{6}{|l|}{ Ingredients, \% } \\
\hline Corn & 78.191 & 78.191 & 78.191 & 78.191 & 78.191 \\
\hline Soybean meal & 18.400 & 13.800 & 9.200 & 4.600 & - \\
\hline GuarPro F-71 & - & 3.709 & 7.418 & 11.127 & 14.836 \\
\hline Poultry fat & - & 0.686 & 1.387 & 2.037 & 2.754 \\
\hline L-Lysine-HCL, 78.8\% & 0.470 & 0.530 & 0.590 & 0.640 & 0.700 \\
\hline DL-Methionine & 0.060 & 0.070 & 0.080 & 0.090 & 0.100 \\
\hline L-Threonine & 0.150 & 0.170 & 0.200 & 0.230 & 0.260 \\
\hline L-Tryptophan & 0.030 & 0.030 & 0.030 & 0.030 & 0.030 \\
\hline L-Isoleucine & - & 0.035 & 0.065 & 0.100 & 0.140 \\
\hline L-Valine & 0.040 & 0.070 & 0.090 & 0.120 & 0.150 \\
\hline L-Cysteine HCL & 0.079 & 0.079 & 0.079 & 0.079 & 0.079 \\
\hline L-Phenylalanine & - & 0.050 & 0.090 & 0.140 & 0.180 \\
\hline Limestone & 0.750 & 0.750 & 0.750 & 0.750 & 0.750 \\
\hline Dicalcium phosphate & 1.500 & 1.500 & 1.500 & 1.500 & 1.500 \\
\hline Salt & 0.180 & 0.180 & 0.180 & 0.180 & 0.180 \\
\hline Mineral premix² & 0.080 & 0.080 & 0.080 & 0.080 & 0.080 \\
\hline Vitamin premix ${ }^{3}$ & 0.070 & 0.070 & 0.070 & 0.070 & 0.070 \\
\hline \multicolumn{6}{|l|}{ Major nutrient parameter ${ }^{4}, \%$} \\
\hline Gross energy, kcal/kg & 3,862 & 3,887 & 3,968 & 4,056 & 4,091 \\
\hline Dry matter & 88.3 & 88.3 & 88.4 & 88.8 & 89.2 \\
\hline Crude protein & 13.5 & 13.8 & 14.3 & 14.9 & 15.3 \\
\hline Crude fibre & 2.02 & 2.14 & 1.97 & 2.14 & 2.34 \\
\hline Ether extract & 2.66 & 3.72 & 4.29 & 5.26 & 5.97 \\
\hline Ash & 4.35 & 3.67 & 3.81 & 3.67 & 3.66 \\
\hline
\end{tabular}

1 Diets 2, 3, 4, and 5 were formulated with inclusion of GuarPro F-71 to replace 25, 50, 75, and 100\% soybean meal in diet 1 (on an equivalent CP basis), respectively.

${ }^{2}$ Mineral premix (no. NB-8534) was donated from Nutra Blend, LLC (Neosho, MO) that provided (per kg of diet): Cu, $8.80 \mathrm{mg} ; \mathrm{Fe}, 88.0 \mathrm{mg} ; \mathrm{l}, 0.16 \mathrm{mg} ; \mathrm{Mn}, 20.8$ $\mathrm{mg} ; \mathrm{Zn}, 88.0 \mathrm{mg}$, and Se, $0.16 \mathrm{mg}$.

3 Vitamin premix (no. NB-6508A) was donated from Nutra Blend, LLC (Neosho, MO) that provided (per kg of diet): vitamin A, 3,080 IU; vitamin D3, 385 IU; vitamin E, $12.3 \mathrm{IU}$; vitamin K, $1.23 \mathrm{mg}$; vitamin B2, $2.31 \mathrm{mg}$; niacin, $13.9 \mathrm{mg}$; vitamin B5, $7.70 \mathrm{mg}$; and vitamin B12, $10.8 \mu \mathrm{g}$.

${ }^{4}$ The proximate and gross energy analyses were conducted on 3 samples per diet at the Essig Animal Nutrition Laboratory, Mississippi State University (Starkville, MS). The unit for gross energy was kcal/kg instead of percentage.

and stored at $-80^{\circ} \mathrm{C}$ until analysis of nutrient metabolites. Batch analysis was performed using the automated ACE Alera Clinical Chemistry System (Alfa Wassermann, West Caldwell, NJ, USA) for determination of seven plasma metabolites, which included plasma urea nitrogen, total protein, albumin, glucose, cholesterol, and triglycerides with six respective ACE reagents (Alfa Wassermann) at the College of Veterinary Medicine Diagnostic Laboratory at Mississippi State University (Regmi et al., 2018).

\section{Statistical analysis}

Initial BW were analysed by ANOVA using the GLM procedure of SAS (SAS Inst. Inc., Cary, NC, USA). Means were separated by LSD. All other data were analysed using ANCOVA using the GLM procedure of SAS. Initial $\mathrm{BW}$ served as a covariate. The relationships between the dietary GP71 inclusion rate and the growth performance parameters were determined using orthogonal polynomial contrasts for linear, quadratic, and cubic effects. Probability value less than or equal to 0.05 was considered as significant, and less than or equal to 0.10 as a trend.

\section{Results and discussion}

\section{Animal growth performance}

The effects of dietary GP71 inclusion on the growth performance of the growing pigs are shown in Table 2. The initial BW of the pigs fed diet 1 (i.e. basal control diet without GP71 inclusion) was greater $(P<0.05)$ than the BW of the pigs fed diets 2 and 4 , and there was a significant difference between the pigs fed Diets 4 and 5 . These initial BW differences existed before the dietary treatment was applied and, therefore, were randomly attained during pen and treatment assignment. Because of this, all the response parameters measured in this study were analysed with initial $\mathrm{BW}$ serving as a covariate in the ANCOVA statistical model.

The ADFI of the pigs was decreased by the dietary inclusion of GP71, showing a significant quadratic $(P=0.014)$ relationship (Table 2). This finding was in line with Karpiesiuk et al. (2018), who reported that the replacement of soybean meal with guar meal by 50 to $75 \%$ (but not at $25 \%$ ) severely reduced the ADFI in finishing pigs. As 
Table 2. Growth performance of the growing pigs fed with five experimental diets. ${ }^{1,2}$

\begin{tabular}{|c|c|c|c|c|c|c|c|c|}
\hline \multirow[t]{2}{*}{ Item } & \multicolumn{5}{|c|}{ Experimental diets } & \multicolumn{3}{|c|}{$P$-value } \\
\hline & Diet 1 & Diet 2 & Diet 3 & Diet 4 & Diet 5 & Linear & Quadratic & Cubic \\
\hline $\begin{array}{l}\text { Initial BW, kg } \\
\text { Final BW, kg } \\
\text { ADG, kg } \\
\text { ADFI, kg } \\
\text { G:F ratio }\end{array}$ & $\begin{array}{l}33.5 \pm 2.24^{a} \\
64.9 \pm 5.16 \\
1.12 \pm 0.12 \\
2.51 \pm 0.11 \\
0.45 \pm 0.03^{b}\end{array}$ & $\begin{array}{l}31.1 \pm 1.11^{\mathrm{b}, \mathrm{c}} \\
59.5 \pm 1.04 \\
1.02 \pm 0.03 \\
1.88 \pm 0.15 \\
0.54 \pm 0.05^{\mathrm{a}}\end{array}$ & $\begin{array}{l}32.0 \pm 1.38^{\mathrm{a}, \mathrm{b}, \mathrm{c}} \\
57.8 \pm 5.33 \\
0.92 \pm 0.17 \\
2.08 \pm 0.28 \\
0.44 \pm 0.02^{\mathrm{b}, \mathrm{c}}\end{array}$ & $\begin{array}{l}29.9 \pm 1.41^{c} \\
52.4 \pm 2.47 \\
0.81 \pm 0.14 \\
1.89 \pm 0.11 \\
0.44 \pm 0.02^{b, c}\end{array}$ & $\begin{array}{l}33.1 \pm 1.00^{\mathrm{a}, \mathrm{b}} \\
54.2 \pm 3.05 \\
0.75 \pm 0.10 \\
2.03 \pm 0.12 \\
0.37 \pm 0.04^{\mathrm{c}}\end{array}$ & $\begin{array}{l}\mathrm{N} / \mathrm{A} \\
0.000 \\
0.000 \\
0.004 \\
0.001\end{array}$ & $\begin{array}{l}\text { N/A } \\
0.956 \\
0.969 \\
0.014 \\
0.043\end{array}$ & $\begin{array}{l}\mathrm{N} / \mathrm{A} \\
0.878 \\
0.882 \\
0.109 \\
0.033\end{array}$ \\
\hline
\end{tabular}

${ }^{1}$ Diets 2, 3, 4, and 5 were formulated with inclusion of GuarPro F-71 to replace $25,50,75$, and $100 \%$ soybean meal in Diet 1 (on an equivalent CP basis), respectively.

${ }^{2}$ Means $( \pm S D)$ within a row that do not share a common superscript differ $(P<0.05)$.

already known, feed intake can be influenced by palatability and animal adaptation to new feed ingredients (Gilani et al., 2005). Guar meal unpalatability has been reported previously in other livestock species. Rahman and Leighton (1968) reported a palatability issue of guar meal in dairy cows. In beef cattle, steers, fed raw or toasted guar meal ( $2.8 \mathrm{~kg} / \mathrm{head} /$ day with ad libitum sorghum silage), exhibited mild scouring and signs of reluctance to eat (Conrad et al., 1967). Therefore, some palatability issue in diets containing high levels of guar meal may have reduced feed intake in the current trial.

This finding regarding feed intake, however, contradicts the result of Heo et al. (2009) who reported no significant effect of guar meal diets on ADFI in growing-finishing pigs. This discrepancy may be attributed to the length of feeding period. Pigs in the Heo et al. (2009) trial were fed from 29.7 $\mathrm{kg}$ until finishing ( 90.1 to $103.9 \mathrm{~kg}$ ) and, would have been better adapted to the diets during the growing stage. The age of the pigs and the levels of guar meal inclusion were different than those of the current study. It is known that a prolonged period of feeding may help animals to adapt better to a new feed ingredient, such as guar meal, and allows compensatory recovery of feed intake and growth.

Feed efficiency (expressed as the G:F ratio) showed linear $(P=0.001)$, quadratic $(P=0.043)$ and cubic $(P=0.033)$ relations with dietary GP71 inclusion rate (Table 2). Based on the effect of the cubic relationship, pigs fed diet 2 (25\% GP71 replacement) had the higher $(P<0.05) \mathrm{G}: \mathrm{F}$ ratio than pigs fed diets 1, 3 and 4 , which in turn were higher $(P<0.05)$ than pigs fed diet 5 (100\% soybean meal replacement). This finding suggested that the soybean meal replacement by GP71 at a level up to $75 \%$ did not negatively affect the feed efficiency of the growing pigs. This result partially agreed with the findings of Heo et al. (2009), who reported that the increased inclusion of guar meal linearly decreased the G:F ratio in growing-finishing pigs. Karpiesiuk et al. (2018) reported that the replacement of soybean meal with guar meal at the levels of 50 and $75 \%$ severely reduced the G:F ratio in finishing pigs.
The ADG and final BW linearly declined $(P<0.001)$ with increasing levels of GP71 in the diets. Heo et al. (2009) found similar results in growing-finishing pigs, whereby ADG and final BW decreased with increased inclusion of guar meal. Recently, Karpiesiuk et al. (2018) reported that the replacement of soybean meal with guar meal at levels of 50 and $75 \%$ severely reduced the ADG and final $\mathrm{BW}$ in finishing pigs. Obviously, the negative impact of the dietary GP71 inclusion on the ADG of the pigs in the current study could be attributed to reduced ADFI, but were not necessarily related to the G:F ratio. The G:F ratio was only significantly reduced when the pigs were fed diet 5 (100\% soybean meal replacement).

Guar meal may be a cheap source of protein, but it usually contains approximately $8 \%$ guar gum residual (non-starch polysaccharides). Hussain et al. (2012) stated that guar meal that usually contains 14 to $20 \%$ residual guar gum can negatively affect broiler chicken's feed intake and growth rates. McDonald et al. (1999) reported that 10\% inclusion of guar gum in a white rice-based diet was associated with reduced BW gain in weaner pigs. Owusu-Asiedu et al. (2006) reported that feeding of guar gum diets for 14 days lowered feed intake by $227 \mathrm{~g} / \mathrm{d}$ in growing pigs. In the current study, pigs fed GP71 diets (diets 2 to 5) consumed 17 to $25 \%$ less feed than the pigs receiving the control diet (diet 1). As a result, pigs fed the diets containing GP71 might not have had sufficient dietary nutrients (e.g. energy and protein or amino acids) available for digestion and absorption in the first place.

In terms of feed efficiency, various factors, including nutrient digestibility and availability, have a major impact (Hassan et al., 2010; Tuśnio et al., 2017). Guar gum typically contains highly viscous non-starch polysaccharides, such as galactomannan polysaccharide (65\% mannose and 35\% galactose) (Lee et al., 2003; Owusu-Asiedu et al., 2006). A high concentration of dietary non-starch polysaccharides or fibre can increase digesta viscosity, inhibit digestive enzyme activities and reduce nutrient digestibility ( $\mathrm{Li} e t$ al., 2004; McDonald et al., 1999). Previous research (Lee et 
al., 2003; Vohra and Krazter, 1964) reported that chickens fed high guar meal-containing diets had high intestinal viscosity which caused growth depression. In the current study, a replacement of 50 to $100 \%$ soybean meal in the diets by GP71 might have increased intestinal viscosity and decreased nutrient digestibility and availability, due to the increased content of residual guar gum and other antinutritional factors (supplemental Table S1). However, it should be kept in mind that no clinical signs of unhealthiness or digestive disturbances were observed in the pigs.

\section{Serum metabolites}

To date, there are no published reports concerning the effects of feeding guar meal on nutrient metabolism in pigs. The effects of GP71 inclusion on the plasma concentrations of nutrient metabolites are presented in Table 3. There were no differences in plasma concentrations of urea nitrogen, total protein, albumin, glucose, total cholesterol or triglycerides among the pigs fed the five different diets $(P>0.152)$. These results partially agreed with the findings of Ahmed and Elkhair (2016), who used 0, 7.5, and 10\% guar meal in replacement of soybean meal in broiler diets. They reported that the plasma concentrations of urea nitrogen, total protein, albumin, total cholesterol or triglycerides were not altered by feeding the $7.5 \%$ guar meal diet. However, the inclusion of $10 \%$ guar meal reduced the plasma concentration of glucose (Ahmed and Elkhair, 2016). Some other reports in broilers found different results. For example, Hafsa et al. (2015) reported that dietary inclusion of guar meal (25 to $75 \%$ ) decreased plasma concentrations of total protein and albumin, but increased the plasma concentrations of urea nitrogen, total cholesterol, and triglycerides. Reddy et al. (2017) reported that the serum concentration of total cholesterol was increased in broilers fed diets containing toasted guar meal (6 to $18 \%$ ). Why dietary guar meal inclusion affected some blood nutrient metabolites in broilers but not in swine warrants further investigation.
Inclusion of any new feed ingredient in animal feed may have undesired impacts on nutrient metabolism and animal health. The analysis of plasma nutrient metabolites can help animal nutritionists uncover preliminary metabolic effects of a new ingredient. Plasma urea nitrogen, total protein and albumin are good indicators of dietary nitrogen utilisation and protein synthesis efficiency (Regmi et al., 2018). In the current study, the unchanged plasma concentrations of total protein, albumin and urea nitrogen indicated that the overall protein metabolism or nitrogen utilisation, including amino acid wastage or muscle protein turnover, was not negatively affected by partial or complete replacement of soybean meal with GP71 in a diet for growing pigs. Furthermore, the unchanged plasma concentrations of glucose, total cholesterol, and triglycerides in this study (Table 3) indicated that energy and lipid metabolism and the health status of the growing pigs were not adversely affected by feeding GP71. Although no previous data is available detailing pig plasma metabolite profiles when feeding guar meal, the profiles from some broiler chicken studies supported these current findings, whereby increasing the inclusion level of GP71 was unlikely to have detrimental effects on the metabolism of glucose and lipids. Taken together, the blood parameters measured in this study suggested that using GP71 as the main protein source to replace soybean meal in diet for growing pigs does not affect the metabolism of major nutrients, including energy, proteins, and lipids.

\section{Conclusions}

Although the blood nutrient metabolites results suggested that dietary inclusion of GP71 as the main protein source does not have any detrimental effects on the nutrient metabolism in growing pigs, the growth performance data indicated that it could negatively affect pigs' feed intake. Feed efficiency, however, was not affected when using GP71 to replace soybean meal up to $75 \%$. Further studies are required to investigate any anti-nutritional factors that may cause reduced feed intake and feed efficiency in growing pigs and to develop nutritional strategies to alleviate such negative impacts on pig growth performance.

Table 3. The concentrations of selected nutrient metabolites in the blood plasma of the growing pigs after four-weeks of the feeding trial. ${ }^{1}$

\begin{tabular}{|c|c|c|c|c|c|c|c|c|}
\hline \multirow[t]{2}{*}{ Item } & \multicolumn{5}{|c|}{ Experimental diets } & \multicolumn{3}{|l|}{$P$-value } \\
\hline & Diet 1 & Diet 2 & Diet 3 & Diet 4 & Diet 5 & Linear & Quadratic & Cubic \\
\hline $\begin{array}{l}\text { Urea nitrogen, } \mathrm{mg} / \mathrm{dl} \\
\text { Total protein, } \mathrm{mg} / \mathrm{dl} \\
\text { Albumin, } \mathrm{mg} / \mathrm{dl} \\
\text { Glucose, mg/dl } \\
\text { Total cholesterol, mg/dl } \\
\text { Triglycerides, mg/dl }\end{array}$ & $\begin{array}{l}8.00 \pm 0.24 \\
6.05 \pm 0.33 \\
3.60 \pm 0.29 \\
96.8 \pm 3.95 \\
73.7 \pm 10.69 \\
51.0 \pm 5.94\end{array}$ & $\begin{array}{l}7.75 \pm 2.06 \\
6.23 \pm 0.22 \\
3.83 \pm 0.21 \\
100.0 \pm 4.69 \\
72.0 \pm 9.83 \\
46.3 \pm 8.77\end{array}$ & $\begin{array}{l}11.25 \pm 3.40 \\
5.95 \pm 0.24 \\
3.63 \pm 0.59 \\
100.2 \pm 10.40 \\
69.0 \pm 12.11 \\
51.7 \pm 16.68\end{array}$ & $\begin{array}{l}9.00 \pm 1.63 \\
6.38 \pm 0.22 \\
3.90 \pm 0.44 \\
101.0 \pm 3.56 \\
74.2 \pm 9.74 \\
55.5 \pm 21.21\end{array}$ & $\begin{array}{l}11.60 \pm 4.42 \\
6.00 \pm 0.31 \\
3.52 \pm 0.37 \\
100.4 \pm 4.51 \\
73.4 \pm 11.90 \\
41.4 \pm 12.20\end{array}$ & $\begin{array}{l}0.268 \\
0.616 \\
0.947 \\
0.503 \\
0.756 \\
0.564\end{array}$ & $\begin{array}{l}0.927 \\
0.353 \\
0.931 \\
0.973 \\
0.550 \\
0.238\end{array}$ & $\begin{array}{l}0.888 \\
0.405 \\
0.968 \\
0.716 \\
0.504 \\
0.152\end{array}$ \\
\hline
\end{tabular}

1 Diets 2, 3, 4, and 5 were formulated with inclusion of GuarPro F-71 to replace $25,50,75$, and $100 \%$ soybean meal in Diet 1 (on an equivalent CP basis), respectively. 


\section{Acknowledgements}

This research was financially supported in part by USDANIFA Hatch/Multistate Project 1007691 and Mississippi State University MAFES/FWRC Director's Doctoral Fellowship (2015 to 2019). Donations of various feed ingredients from Shree Ram India Gums Pvt Ltd (Rajasthan, India), Evonik Nutrition \& Care GmbH (Hanau-Wolfgang, Germany), and Nutra Blend, LLC (Neosho, MO, USA) are greatly acknowledged. Authors wish to thank Mr. William White (Farm Manager, Leveck Animal Research Center, Mississippi State University) and other colleagues for their support in facility and animal management.

\section{Declaration of interest}

Authors declare that they have no conflicts of interest.

\section{Supplementary material}

Supplementary material can be found online at https://doi. org/10.3920/JAAN2020.0015.

Table S1. The vitamin profile and some antinutritional factors contained in GuarPro-F71 (as-fed basis).

Table S2. The calculated nutrient and energy composition of the five experimental diets (\% or as indicated, as-fed basis).

\section{References}

Ahmed, H.A. and Elkhair, R.M.A., 2016. Potential application of guar meal in broiler diet. Asian Journal of Animal and Veterinary Advances 11: 280-287. https://doi.org/10.3923/ajava.2016.280.287

Conner, S. R. 2002. Characterization of guar meal for use in poultry rations. PhD Dissertation, Texas A\&M University, College Station, TX, USA.

Conrad, B.E., Neal, E.M. and Riggs, J.K., 1967. Guar meal for beef cattle. Journal of Animal Science 26: 219.

Couch, J.R., Bakshi, Y.K., Ferguson, T.M., Smith, E.B. and Creger. C.R., 1967. The effect of processing on the nutritional value of guar meal for broiler chicks. British Poultry Science 8: 243-250. https://doi. org/10.1080/00071666708415675

Gilani, G.S., Cockell, K.A. and Sepehr, E., 2005. Effects of antinutritional factors on protein digestibility and amino acid availability in foods. Journal of AOAC International 88: 967-987. https://doi.org/10.1093/ jaoac/88.3.967

Gutierrez, O., Zhang, C., Cartwright, A.L., Carey, J.B. and Bailey, C.A., 2007. Use of guar by-products in high-production laying hen diets. Poultry Science 86: 1115-1120. https://doi.org/10.1093/ps/86.6.1115 Hafsa, S.H.A., Basyony, M.M. and Hassan, A.A., 2015. Effect of partial replacement of soybean meal with different levels of guar korma meal on growth performance, carcass traits and blood metabolites of broiler chickens. Asian Journal of Poultry Science 9: 112-122. https://doi.org/10.3923/ajpsaj.2015.112.122
Hassan, S.M., Haq, A.U., Byrd, J.A., Berhow, M.A., Cartwright, A.L. and Bailey, C.A., 2010. Haemolytic and antimicrobial activities of saponin-rich extracts from guar meal. Food Chemistry 119: 600605. https://doi.org/10.1016/j.foodchem.2009.06.066

Heo, P.S., Lee, S.W., Kim, D.H., Lee, G.Y., Kim, K.H. and Kim, Y.Y., 2009. Various levels of guar meal supplementation on growth performance and meat quality in growing-finishing pigs (Abstract). Journal of Animal Science 87 (E-Suppl. 2): 144.

Humphrey, R.M., Yang, Z., Hasan, M.S., Crenshaw, M.A., Brett, J., Rude, B.J., Bubba Burch, H.B. and Liao. S. F., 2018. Amino acid profile of Guarpro F-71, a potential protein source for swine and other agricultural animals in the United States. Journal of Animal Science 96: 275-276. https://doi.org/10.1093/jas/sky073.514

Hussain, M., Rehman, A.U. and Khalid, M.F., 2012. Feeding value of guar meal and the application of enzymes in improving nutritive value for broilers. World's Poultry Science Journal 68: 253-268. https://doi.org/10.1017/S0043933912000311

Huston, J.E. and Shelton, M., 1971. An evaluation of various protein concentrates for growing finishing lambs. Journal of Animal Science 32: 334-348. https://doi.org/10.2527/jas1971.322334x

Kamran, M., Pasha, T.N., Mahmud, A. and Ali, Z., 2002. Effect of commercial enzyme (natugrain) supplementation on the nutritive value and inclusion rate of guar meal in broiler rations. International Journal of Poultry Science 1: 167-173. https://doi.org/10.3923/ ijps.2002.167.173

Karpiesiuk, K., Bugnacka, D., Jarocka, B., Kozera, W. and Woźniakowska, A., 2018. The effect of partial replacement of soybean meal protein with guar (Cyamopsis tetragonoloba) meal protein on the cost-effectiveness of pig fattening. Annals of Warsaw University of Life Sciences 57: 341-348. https://doi.org/10.22630/ AAS.2018.57.4.33

Kim, H.J., Nam, S.O., Jeong, J.H., Fang, L.H., Yoo, H.B., Yoo, S.H., Hong, J.S., Son, S.W., Ha, S.H. and Kim, Y.Y., 2017. Various levels of copra meal supplementation with $\beta$-mannanase on growth performance, blood profile, nutrient digestibility, pork quality and economical analysis in growing-finishing pigs. Journal of Animal Science and Technology 59: 19. https://doi.org/10.1186/s40781-017-0144-6

Lee, J.T., Bailey, C.A. and Cartwright, A.L., 2003. Guar meal germ and hull fractions differently affect growth performance and intestinal viscosity of broiler chickens. Poultry Science 82: 1589-1595. https:// doi.org/10.1093/ps/82.10.1589

Lee, J.T., Connor-Appleton, S., Bailey, C.A. and Cartwright, A.L., 2005. Effects of guar meal by-product with and without beta-mannanase Hemicell on broiler performance. Poultry Science 84: 1261-1267. https://doi.org/10.1093/ps/84.8.1261

Li, W.F., Feng, J., Xu, Z.R. and Yang, C.M., 2004. Effects of non-starch polysaccharides enzymes on pancreatic and small intestinal digestive enzyme activities in piglet fed diets containing high amounts of barley. World Journal of Gastroenterology 10: 856-859. https:// doi.org/10.3748/wjg.v10.i6.856

Liao, S.F., Hasan, M.S., Humphrey, R.M., Yang, Z., Crenshaw, M.A., Brett, J., Rude, B.J. and Bubba Burch, H.B., 2018. The mineral profile of GuarPro F-71, a potential protein source for swine and other agricultural animals in the United States. Journal of Animal Science 96 (Suppl_3): 327-328. https://doi.org/10.1093/jas/sky404.720 
McDonald, D.E., Pethick, D.W., Pluske, J.R. and Hampson, D.J., 1999. Adverse effects of soluble non-starch polysaccharide (guar gum) on piglet growth and experimental colibacillosis immediately after weaning. Research in Veterinary Science 67: 245-250. https://doi. org/10.1053/rvsc.1999.0315

McGlone, J. and Pond, W.G., 2003. Pig production: biological principles and applications. $1^{\text {st }}$ ed. Thomson Delmar Learning, Clifton Park, NY, USA.

Mudgil, D., Barak, S. and Khatkar, B.S., 2014. Guar gum: processing, properties and food applications-A Review. Journal of Food Science and Technology 51: 409-418. https://doi.org/10.1007/s13197-0110522-x

National Research Council (NRC), 2012. Nutrient requirements of swine. $11^{\text {th }}$ revised edition. The National Academies Press, Washington, DC, USA. https://doi.org/10.17226/13298

Owusu-Asiedu, A., Patience, J.F., Laarveld, B., Van Kessel, A.G., Simmins, P.H. and Zijlstra, R.T., 2006. Effects of guar gum and cellulose on digesta passage rate, ileal microbial populations, energy and protein digestibility, and performance of grower pigs. Journal of Animal Science 84: 843-852. https://doi.org/10.2527/2006.844843x

Patience, J.F., Rossoni-Serão, M.C. and Gutiérrez, N.A., 2015. A review of feed efficiency in swine: biology and application. Journal of Animal Science and Biotechnology 6:33. https://doi.org/10.1186/ s40104-015-0031-2

Rahman, M.S. and Leighton, R.E., 1968. Guar meal in dairy rations. Journal of Dairy Science 51: 1667-1671. https://doi.org/10.3168/ jds.S0022-0302(68)87249-2
Reddy, E.T., Reddy, V.R., Preetham, V.C., Rao, S.R. and Rao, D.S., 2017. Effect of dietary inclusion of graded levels of toasted guar meal on performance, nutrient digestibility, carcass traits, and serum parameters in commercial broiler chickens. Tropical Animal Health and Production 49: 1409-1414. https://doi.org/10.1007/ s11250-017-1341-5

Regmi, N., Wang, T., Crenshaw, M.A., Rude, B.J. and Liao, S.F., 2018. Effects of dietary lysine levels on the concentrations of selected nutrient metabolites in blood plasma of late-stage finishing pigs. Journal of Animal Physiology and Animal Nutrition 102: 403-409. https://doi.org/10.1111/jpn.12714

Schmit, T.M., Verteramo, L.J. and Tomek, W.G., 2009. Implications of growing biofuel demands on northeast livestock feed costs. Agricultural and Resource Economics Review 38: 200-212. https:// doi.org/10.22004/ag.econ.55540

Tuśnio, A., Taciak, M., Barszcz, M., Święch, E., Bachanek, I. and Skomiał. J., 2017. Effect of replacing soybean meal by raw or extruded pea seeds on growth performance and selected physiological parameters of the ileum and distal colon of pigs. PLoS ONE 12: e0169467. https://doi.org/10.1371/journal.pone.0169467

Velayudhan, D.E., Kim, I.H. and Nyachoti. C.M., 2015. Characterization of dietary energy in swine feed and feed ingredients: a review of recent research results. Asian-Australasian Journal of Animal Sciences 28: 1-13. https://doi.org/10.5713/ajas.14.0001R

Vohra, P. and Kratzer, F.H., 1964. The use of guar meal in chicken rations. Poultry Science 43: 502-503. https://doi.org/10.3382/ ps.0430502 
